\title{
Pertumbuhan dan Hasil Tanaman Terung ( Solanum melongena L.) pada Berbagai Dosis Bahan Organik dan Kombinasi Pupuk N, P dan K
}

\author{
Growth and Results of Eggplant (Solanum melongena L.) at Various Doses of Organic \\ Matter and Combination of $N, P$ and $K$ Fertilizers
}

\author{
Tajul Rina ${ }^{1}$, Ashabul Anhar ${ }^{1}$ dan Ainun Marliah ${ }^{1 *}$ \\ ${ }^{1}$ Program Studi Agroteknologi, Fakultas Pertanian, Universitas Syiah Kuala
}

\begin{abstract}
Abstrak. Penelitian bertujuan untuk mengetahui pengaruh dosis bahan organik dan kombinasi pupuk N, P dan K terhadap pertumbuhan dan hasil tanaman terung. Penelitian ini dilaksanakan di kebun percobaan sektor selatan, Fakultas Pertanian, Universitas Syiah Kuala, yang telah berlangsung dari bulan Desember sampai dengan April 2017. Rancangan yang digunakan adalah Rancangan Acak Kelompok (RAK) pola faktorial $4 \mathrm{x} 4$ dengan tiga ulangan. Faktor yang diteliti yaitu dosis bahan organik yang terdiri dari 4 taraf yaitu kontrol, tanah + pupuk kandang $(80 \%: 20 \%)$, tanah + pupuk kandang $(60 \%: 40 \%)$, tanah + pupuk kandang $(40 \%: 60 \%)$. Faktor kedua yaitu kombinasi pupuk N, P dan K terdiri atas 4 taraf yaitu kontrol, urea $100 \mathrm{~kg}+\mathrm{SP} 3650 \mathrm{~kg}+\mathrm{KCl} 25 \mathrm{Kg} / \mathrm{ha}$, urea $200 \mathrm{~kg}+\mathrm{SP} 36100 \mathrm{~kg}+\mathrm{KCl} 50 \mathrm{~kg} / \mathrm{ha}$, urea $300 \mathrm{~kg}+\mathrm{SP} 36150 \mathrm{~kg}+\mathrm{KCl} 75 \mathrm{~kg} / \mathrm{ha}$. Hasil penelitian menunjukkan bahwa dosis bahan organik berpengaruh sangat nyata terhadap tinggi tanaman umur 30 dan 45 HSPT, diameter batang umur 15, 30 dan 45 HSPT, jumlah daun umur 15, 30 dan 45 HSPT, jumlah buah tanaman terung, panjang buah terung, diameter buah terung, berat buah terung, berat berangkasan basah dan berat berangsan kering. Hasil penelitian juga menunjukkan bahwa kombinasi pupuk N, P dan K berpengaruh sangat nyata terhadap tinggi tanaman umur 30 HSPT, diameter batang umur 15, 30 dan 45 HSPT, jumlah daun umur 15, 30 dan 45 HSPT, jumlah buah pertanaman, panjang buah pertanaman, diameter buah pertanaman, berat buah terung, berat berangkasan basah dan berat berangkasan kering. Hasil penelitian juga menunjukkan bahwa pertumbuhan dan hasil tanaman terung dipengaruhi oleh interaksi yang sangat nyata terhadap parameter tinggi tanaman umur 30 HSPT, diameter buah terung, berat buah terung, dan berat berangkasan kering. Hasil penelitian dapat disimpulkan bahwa terdapat interaksi antara dosis bahan organik dan kombinasi pupuk N, P dan $\mathrm{K}$ terhadap pertumbuhan dan hasil tanaman terung. Interaksi antara perlakuan dosis bahan organik $40 \%$ (D2) dengan kombinasi pupuk N $200 \mathrm{~kg}$, P $100 \mathrm{~kg}$ dan K $50 \mathrm{~kg} / \mathrm{ha}(\mathrm{K} 2)$ merupakan kombinasi perlakuan terbaik untuk pertumbuhan dan hasil tanaman terung.
\end{abstract}

Kata kunci: Terung, Bahan organik, Kombinasi pupuk N, P dan K

Abstrack. The study aimed to determine the effect of organic matter dosage and combination of N, P and K fertilizer on the growth and yield of eggplant. This research was carried out in the southern sector experimental garden, Faculty of Agriculture, Syiah Kuala University, which has been going on from December to April 2017. The design used was a Randomized Block Design (RAK) $4 \times 4$ factorial pattern with three replications. The factors studied were the dose of organic matter consisting of 4 levels, namely control, soil + manure $(80 \%$ : $20 \%)$, soil + manure $(60 \%: 40 \%)$, soil + manure $(40 \%: 60 \%)$. The second factor is a combination of N, P and K fertilizers consisting of 4 levels namely control, $100 \mathrm{~kg}$ urea + SP36 $50 \mathrm{~kg}+\mathrm{KCl} 25 \mathrm{Kg} / \mathrm{ha}, 200 \mathrm{~kg}$ urea + SP36 $100 \mathrm{~kg}+50 \mathrm{~kg} \mathrm{KCl} / \mathrm{ha}, 300 \mathrm{~kg}+\mathrm{SP} 36 \mathrm{Kure} 150 \mathrm{~kg}+\mathrm{KCl} 75 \mathrm{~kg} /$ ha. The results showed that the dose of organic matter had a very significant effect on the height of plants aged 30 and 45 days after transplanting, stem diameter aged 15, 30 and 45 days after transplanting, the number of leaves aged 15, 30 and 45 days after transplanting, the number fruit of eggplant plants, length of eggplant fruit, diameter of eggplant fruit, weight of eggplant fruit, weight of wet eggplant and weight of dried eggplant. The results also showed that the combination of N, P and $\mathrm{K}$ fertilizer had a very significant effect on plant height at 30 days after transplanting, stem diameter aged 15, 30 and 45 days after transplanting, the number of leaves aged 15, 30 and 45 days after transplanting, the number of fruit planted, the length of the planting fruit, the diameter of the planting fruit, the weight of the eggplant fruit, the weight of the wet fruit and the weight of the dried seedlings. The results also showed that the growth and yield of eggplant plants were influenced by a very real interaction on the parameters of plant height 30 days after transplanting, eggplant fruit diameter, eggplant fruit weight, and dry weight. The results of this study concluded that there was an interaction between the dose of organic matter and the

Pertumbuhan dan Hasil Tanaman Terung ( Solanum melongena L.) pada Berbagai Dosis Bahan Organik dan Kombinasi Pupuk N, P dan K (Tajul Rina, Ashabul Anhar, Ainun Marliah) 
combination of N, P and K fertilizer on the growth and yield of eggplant. The interaction between the treatment of $40 \%$ organic matter (D2) with a combination of $200 \mathrm{~kg} \mathrm{~N}$ fertilizer, $100 \mathrm{~kg} \mathrm{P}$ and $50 \mathrm{~kg} / \mathrm{ha} \mathrm{K}$ (K2) was the best treatment combination for eggplant growth and yield.

Keywords: Eggplant, organic matter, combination of fertilizer N, P and K

\section{PENDAHULUAN}

Terung (Solanum melongena L.) adalah tanaman asli daerah tropis. Tanaman ini berasal dari benua Asia yaitu India dan Birma. Daerah penyebaran tanaman terung antara lain di Karibia, Malaysia, Afrika Barat, Afrika Tengah, Afrika Timur, dan Amerika Selatan. Tanaman terung menyebar ke seluruh dunia, baik di negara-negara yang beriklim panas (tropis) maupun iklim sedang (sub tropis). Pengembangan budidaya terung paling pesat di Asia Tenggara, salah satunya di Indonesia (Firmanto, 2011).

Menurut Badan Pusat Statistik dan Direktorat Jendral Hortikultura 2016, pada tahun 2011-2015 produksi tanaman terung di Indonesia cenderung terus meningkat, yaitu sebesar 9,95 ton/ha, 10,26 ton/ha, 10,76 ton/ha, 10,95 ton/ha, dan 11,20 ton/ha. Meskipun produktifitas terung nasional tiap tahun meningkat namun di Indonesia produksi terung masih rendah dan hanya menyumbang $1 \%$ dari kebutuhan dunia (Simatupang, 2010).

Berdasarkan hasil penelitian Doni et al. (2015) menyatakan dosis pupuk kandang sapi $40 \%$ menghasilkan produksi yang terbaik pada tanaman terung ungu dan terung hijau yaitu $7,26 \mathrm{~g}$ dengan berat buah terung pertanaman 145,7200 g. Keadaan ini disebabkan dengan pemberian pupuk kandang sapi, maka unsur hara makro dan mikro yang dibutuhkan tanaman dapat di penuhi, juga karena terjadinya perbaikan terhadap sifat fisik dan sifat biologis tanah, sehingga tanaman terung dapat tumbuh dengan subur dan menghasilkan peroduksi buah yang tinggi.

Selain penggunaan pupuk kandang sapi, usaha lain dalam meningkatkan produksi dapat dilakukan dengan cara pemupukan anorganik yaitu pupuk N, P, dan K. Pupuk yang mengandung unsur Nitrogen, Fosfat, dan Kalium merupakan kunci utama dalam usaha budidaya tanaman terung ungu. Pupuk N, P, dan K mempunyai kelebihan dan kekurangan masing-masing sehingga diperlukan informasi mengenai pupuk organik dan anorganik yang paling sesuai untuk memenuhi kebutuhan tanaman terung ungu.

Berdasarkan hasil penelitian Ichan et al. (2015) menyatakan hasil dari pemupukan Urea dapat meningkatkan produksi Okra terbaik pada dosis $200 \mathrm{~kg} / \mathrm{ha}$ dengan berat buah per petak yaitu 7700,17 g. Selanjutnya hasil penelitian Santoso dan Oktariana (2016) menyatakan dosis pupuk SP36 $100 \mathrm{~kg} / \mathrm{ha}$ dan dosis $150 \mathrm{~kg} / \mathrm{ha}$ sebagai perlakuan dengan hasil terbaik pada tanaman okra dengan jumlah rata-rata 28-29 buah per sampel. Selanjutnya hasil penelitian Juandi (2014) menyatakan dosis pupuk $\mathrm{KCl} 50 \mathrm{~kg} / \mathrm{ha}$ dapat menghasilkan berat buah per tanaman terbaik pada labu kuning yaitu $1,61 \mathrm{~kg}$.

Berdasarkan uraian diatas, maka perlu dilakukan penelitian tentang dosis bahan organik dan kombinasi pupuk N, P, dan K terhadap pertumbuhan dan hasil tanaman terung.

\section{METODE PENELITIAN}

\section{Tempat dan Waktu Penelitian}

Penelitian ini dilaksanakan pada bulan Desember sampai April 2018 di kebun percobaan sektor selatan, Fakultas Pertanian, Universitas Syiah Kuala, Darussalam, Banda Aceh.

Pertumbuhan dan Hasil Tanaman Terung ( Solanum melongena L.) pada Berbagai Dosis Bahan Organik dan 


\section{Alat dan Bahan Penelitian}

Bahan yang digunakan dalam penelitian ini terdiri dari : benih terung Varietas Mustang, tanah, pupuk kandang, pupuk Urea, pupuk SP36 dan pupuk KCl. Alat-alat yang digunakan dalam penelitian ini yaitu : polibag, ayakan tanah, kertas label, tali rafia, gunting/pisau, timbangan analitik, meteran/penggaris, alat tulis menulis dan camera.

\section{Rancangan Penelitian}

Rancangan percobaan yang digunakan adalah Rancangan Acak Kelompok (RAK) pola faktorial 4 x 4 dengan 3 ulangan. Adapun faktor yang diteliti yaitu dosis bahan organik dan kombinasi pupuk N, P, dan K. Faktor pertama adalah dosis bahan organik (D) terdiri 4 taraf yaitu: $\left(\mathrm{D}_{0}\right)$ Kontrol, $\left(\mathrm{D}_{1}\right)$ Tanah + Pupuk Kandang $(80 \%: 20 \%),\left(\mathrm{D}_{2}\right)$ Tanah + Pupuk Kandang $(60 \%: 40 \%)$ dan $\left(\mathrm{D}_{3}\right)$ Tanah + Pupuk Kandang $(40 \%: 60 \%)$. Sedangkan faktor kedua adalah kombinasi pupuk $\mathrm{N}, \mathrm{P}$, dan $\mathrm{K}(\mathrm{K})$ terdiri dari 4 taraf yaitu: Kontrol $\left(\mathrm{K}_{0}\right)$, Urea $100 \mathrm{~kg}+\mathrm{SP} 3650 \mathrm{~kg}+\mathrm{KCl} 25 \mathrm{~kg} / \mathrm{ha}\left(\mathrm{K}_{1}\right)$, Urea $200 \mathrm{~kg}+\mathrm{SP} 36100 \mathrm{~kg}+\mathrm{KCl} 50 \mathrm{~kg} / \mathrm{ha}\left(\mathrm{K}_{2}\right)$ dan Urea $300 \mathrm{~kg}+\mathrm{SP} 36150+\mathrm{KCl} 75 \mathrm{~kg} / \mathrm{ha}\left(\mathrm{K}_{3}\right)$

\section{HASIL DAN PEMBAHASAN}

\section{Interaksi}

Berdasarkan analisis ragam (Uji F) menunjukkan interaksi sangat nyata antara perlakuan dosis bahan organik dengan kombinasi pupuk N, P dan K terhadap tinggi tanaman 30 HSPT, diameter buah pertanaman, berat buah pertanaman dan berat berangkasan kering dan terdapat interaksi yang nyata terhadap tinggi tanaman 45 HSPT, jumlah daun 30 HSPT, panjang buah pertanaman dan berat berangkasan basah, namun tidak terdapat interaksi yang nyata terhadap tinggi tanaman 15 HSPT, diameter batang 15, 30 dan 45 HSPT, jumlah daun 15 dan 45 HSPT dan jumlah buah pertanaman.

\section{Tinggi Tanaman Terung Umur 30 HSPT (cm)}

Tabel 1. Rata-rata tinggi tanaman 30 HSPT akibat perlakuan dosis bahan organik dan kombinasi pupuk $\mathrm{N}, \mathrm{P}$ dan $\mathrm{K}$

\begin{tabular}{|c|c|c|c|c|c|c|c|c|}
\hline \multirow{2}{*}{$\begin{array}{c}\text { Dosis } \\
\text { Pupuk } \\
\text { Kandang } \\
(\mathrm{cm}) \\
\end{array}$} & \multicolumn{7}{|c|}{ Kombinasi Pupuk N, p dan K } & \multirow{2}{*}{$\mathrm{BNJ}$} \\
\hline & K0 & \multicolumn{2}{|c|}{ K1 } & \multicolumn{2}{|c|}{$\mathrm{K} 2$} & \multicolumn{2}{|c|}{ K3 } & \\
\hline$\left(\mathrm{D}_{0}\right) 0 \%$ & 18,39 Aa & 23,11 & Aa & 21,67 & $\mathrm{Aa}$ & 21,94 & $\mathrm{Aa}$ & \\
\hline$\left(D_{1}\right) 20 \%$ & $22,61 \mathrm{Aa}$ & 26,33 & $\mathrm{Aa}$ & 26,11 & $\mathrm{ABa}$ & 28,83 & $\mathrm{ABa}$ & 850 \\
\hline$\left(D_{2}\right) 40 \%$ & 22,33 Aa & 28,22 & $\mathrm{Aab}$ & 39,06 & $\mathrm{Cc}$ & 31,45 & $\mathrm{Bbc}$ & 8,50 \\
\hline$\left(D_{3}\right) 60 \%$ & $21,50 \quad \mathrm{Aa}$ & 30,94 & $\mathrm{Ab}$ & 34,17 & $\mathrm{BCb}$ & 28,22 & $\mathrm{ABab}$ & \\
\hline
\end{tabular}

Keterangan : Angka yang diikuti oleh huruf kapital yang sama pada lajur yang sama dan angka yang diikuti oleh huruf kecil yang sama pada baris yang sama berbeda tidak nyata pada taraf $5 \%$ (Uji BNJ ${ }_{0,05}$ ), $\mathrm{K}_{0} ;$ Kontrol, $\mathrm{K}_{1} ;$ Urea $100 \mathrm{~kg} / \mathrm{ha}+\mathrm{SP} 3650 \mathrm{~kg} / \mathrm{ha}+\mathrm{KCl} 25 \mathrm{~kg} / \mathrm{ha}, \mathrm{K}_{2} ;$ Urea $200 \mathrm{~kg} / \mathrm{ha}+\mathrm{SP} 36100$ $\mathrm{kg} / \mathrm{ha}+\mathrm{KCl} 50 \mathrm{~kg} / \mathrm{ha}, \mathrm{K}_{3} ; 300 \mathrm{~kg} / \mathrm{ha}+\mathrm{SP} 36150 \mathrm{~kg} / \mathrm{ha}+\mathrm{KCl} 75 \mathrm{~kg} / \mathrm{ha}$ 


\section{Tinggi Tanaman Terung 45 HSPT $(\mathrm{cm})$}

Tabel 2. Rata-rata tinggi tanaman 45 HSPT akibat perlakuan dosis bahan organik dan kombinasi pupuk N, P dan K

\begin{tabular}{|c|c|c|c|c|c|c|c|c|}
\hline \multirow{2}{*}{$\begin{array}{c}\text { Dosis Pupuk } \\
\text { Kandang } \\
(\mathrm{cm})\end{array}$} & \multicolumn{7}{|c|}{ Kombinasi Pupuk N,P dan K } & \multirow[b]{2}{*}{$\mathrm{BNJ}$} \\
\hline & $\mathrm{K}_{0}$ & $\mathrm{~K}_{1}$ & & $\mathrm{~K}_{2}$ & & $\mathrm{~K}_{3}$ & & \\
\hline$\left(\mathrm{D}_{0}\right) 0 \%$ & $48,11 \mathrm{Aa}$ & 51,83 & $\mathrm{Aa}$ & 51,89 & $\mathrm{Aa}$ & 50,11 & $\mathrm{Aa}$ & \\
\hline$\left(D_{1}\right) 20 \%$ & $59,06 \mathrm{Aa}$ & 61,89 & $\mathrm{Aa}$ & 55,83 & $\mathrm{Aa}$ & 61,94 & $\mathrm{Aa}$ & \\
\hline$\left(D_{2}\right) 40 \%$ & $51,05 \mathrm{Aa}$ & 56,39 & $\mathrm{Aa}$ & 70,89 & $\mathrm{Ab}$ & 59,78 & Aab & \\
\hline$\left(D_{3}\right) 60 \%$ & $58,94 \mathrm{Aa}$ & 63,00 & $\mathrm{Aa}$ & 57,44 & $\mathrm{Aa}$ & 58,50 & $\mathrm{Aa}$ & 13,41 \\
\hline
\end{tabular}

Keterangan : Angka yang diikuti oleh huruf kapital yang sama pada lajur yang sama dan angka yang diikuti oleh huruf kecil yang sama pada baris yang sama berbeda tidak nyata pada taraf $5 \%$ (Uji BNJ ${ }_{0,05}$ ), $\mathrm{K}_{0} ;$ Kontrol, $\mathrm{K}_{1} ;$ Urea $100 \mathrm{~kg} / \mathrm{ha}+\mathrm{SP} 3650 \mathrm{~kg} / \mathrm{ha}+\mathrm{KCl} 25 \mathrm{~kg} / \mathrm{ha}, \mathrm{K}_{2} ;$ Urea $200 \mathrm{~kg} / \mathrm{ha}+\mathrm{SP} 36100$ $\mathrm{kg} / \mathrm{ha}+\mathrm{KCl} 50 \mathrm{~kg} / \mathrm{ha}, \mathrm{K}_{3} ; 300 \mathrm{~kg} / \mathrm{ha}+\mathrm{SP} 36150 \mathrm{~kg} / \mathrm{ha}+\mathrm{KCl} 75 \mathrm{~kg} / \mathrm{ha}$

\section{Jumlah Daun 30 HSPT}

Tabel 3. Rata-rata jumlah daun 30 HSPT akibat perlakuan dosis bahan organik dan kombinasi pupuk N, P dan K

\begin{tabular}{llllllllll}
\hline Dosis Bahan & \multicolumn{8}{c}{ Kombinasi Pupuk N,P,K } & \\
\cline { 2 - 8 } \multicolumn{1}{c}{ Organik } & \multicolumn{2}{c}{$\mathrm{K}_{0}$} & \multicolumn{2}{c}{$\mathrm{K}_{1}$} & $\mathrm{~K}_{2}$ & $\mathrm{~K}_{3}$ & BNJ \\
\hline$\left(\mathrm{D}_{0}\right) 0 \%$ & 4,55 & $\mathrm{Aa}$ & 5,33 & $\mathrm{Aab}$ & 6,00 & $\mathrm{Ab}$ & 4,78 & $\mathrm{Aa}$ & \\
$\left(\mathrm{D}_{1}\right) 20 \%$ & 5,33 & $\mathrm{Aab}$ & 5,11 & $\mathrm{Aa}$ & 6,22 & $\mathrm{Ab}$ & 5,11 & $\mathrm{ABa}$ & \\
$\left(\mathrm{D}_{2}\right) 40 \%$ & 5,00 & $\mathrm{Aa}$ & 5,33 & $\mathrm{Aa}$ & 6,78 & $\mathrm{Ab}$ & 5,89 & $\mathrm{Bab}$ & \\
$\left(\mathrm{D}_{3}\right) 60 \%$ & 4,67 & $\mathrm{Aa}$ & 5,67 & $\mathrm{Aab}$ & 6,00 & $\mathrm{Ab}$ & 4,78 & $\mathrm{Aa}$ & 1,01 \\
\hline
\end{tabular}

Keterangan : Angka yang diikuti oleh huruf kapital yang sama pada lajur yang sama dan angka yang diikuti oleh huruf kecil yang sama pada baris yang sama berbeda tidak nyata pada taraf $5 \%$ (Uji BNJ ${ }_{0,05}$ ), $\mathrm{K}_{0}$; Kontrol, $\mathrm{K}_{1}$; Urea $100 \mathrm{~kg} / \mathrm{ha}+\mathrm{SP} 3650 \mathrm{~kg} / \mathrm{ha}+\mathrm{KCl} 25 \mathrm{~kg} / \mathrm{ha}, \mathrm{K}_{2}$; Urea $200 \mathrm{~kg} / \mathrm{ha}+\mathrm{SP} 36100$ $\mathrm{kg} / \mathrm{ha}+\mathrm{KCl} 50 \mathrm{~kg} / \mathrm{ha}, \mathrm{K}_{3} ; 300 \mathrm{~kg} / \mathrm{ha}+\mathrm{SP} 36150 \mathrm{~kg} / \mathrm{ha}+\mathrm{KCl} 75 \mathrm{~kg} / \mathrm{ha}$

\section{Berat berangkasan basah $(\mathrm{g})$}

Tabel 4. Rata-rata berat berangkasan basah tanaman terung akibat perlakuan dosis bahan organik dan kombinasi pupuk N, P dan K

\begin{tabular}{|c|c|c|c|c|c|c|c|c|c|}
\hline \multirow{2}{*}{$\begin{array}{c}\text { Dosis Bahan } \\
\text { Organik }(\mathrm{g})\end{array}$} & \multicolumn{8}{|c|}{ Kombinasi Pupuk N, P dan K } & \multirow[b]{2}{*}{ BNJ } \\
\hline & \multicolumn{2}{|c|}{$\mathrm{K}_{0}$} & \multicolumn{2}{|c|}{$\mathrm{K}_{1}$} & \multicolumn{2}{|c|}{$\mathrm{K}_{2}$} & \multicolumn{2}{|l|}{$\mathrm{K}_{3}$} & \\
\hline$\left(\mathrm{D}_{0}\right) 0 \%$ & 170,98 & Aa & 203,96 & Aa & 244,43 & $\mathrm{Aa}$ & 146,68 & Aa & \\
\hline$\left(D_{1}\right) 20 \%$ & 264,01 & $\mathrm{Aa}$ & 270,59 & Aa & 325,29 & $\mathrm{Aa}$ & 220,12 & $\mathrm{Aa}$ & \\
\hline$\left(D_{2}\right) 40 \%$ & 207,27 & $\mathrm{Aa}$ & 241,47 & $\mathrm{Aa}$ & 452,10 & $\mathrm{Bb}$ & 223,93 & $\mathrm{Aa}$ & 138,28 \\
\hline$\left(\mathrm{D}_{3}\right) 60 \%$ & 153,52 & $\mathrm{Aa}$ & 320,96 & $\mathrm{Ab}$ & 360,36 & $\mathrm{ABb}$ & 263,70 & $\mathrm{Aab}$ & \\
\hline
\end{tabular}

Keterangan : Angka yang diikuti oleh huruf kapital yang sama pada lajur yang sama dan angka yang diikuti oleh huruf kecil yang sama pada baris yang sama berbeda tidak nyata pada taraf $5 \%$ (Uji BNJ 0.05 ), $\mathrm{K}_{0} ;$ Kontrol, $\mathrm{K}_{1} ;$ Urea $100 \mathrm{~kg} / \mathrm{ha}+\mathrm{SP} 3650 \mathrm{~kg} / \mathrm{ha}+\mathrm{KCl} 25 \mathrm{~kg} / \mathrm{ha}, \mathrm{K}_{2} ;$ Urea $200 \mathrm{~kg} / \mathrm{ha}+\mathrm{SP} 36100$ $\mathrm{kg} / \mathrm{ha}+\mathrm{KCl} 50 \mathrm{~kg} / \mathrm{ha}, \mathrm{K}_{3} ; 300 \mathrm{~kg} / \mathrm{ha}+\mathrm{SP} 36150 \mathrm{~kg} / \mathrm{ha}+\mathrm{KCl} 75 \mathrm{~kg} / \mathrm{ha}$ 


\section{Berat berangkasan kering (g)}

Tabel 5. Rata-rata berat berangkasan basah tanaman terung akibat perlakuan dosis bahan organik dan kombinasi pupuk N, P dan K

\begin{tabular}{lllrlrllll}
\hline Dosis Bahan & \multicolumn{7}{c}{ Kombinasi Pupuk N, P dan K } & \\
\cline { 2 - 8 } Organik (g) & \multicolumn{2}{c}{$\mathrm{K}_{0}$} & $\mathrm{~K}_{1}$ & $\mathrm{~K}_{2}$ & $\mathrm{~K}_{3}$ & BNJ \\
\hline$\left(\mathrm{D}_{0}\right) 0 \%$ & 31,90 & $\mathrm{Aa}$ & 35,33 & $\mathrm{Aa}$ & 49,79 & $\mathrm{Ab}$ & 49,21 & $\mathrm{Bb}$ & \\
$\left(\mathrm{D}_{1}\right) 20 \%$ & 49,56 & $\mathrm{BCb}$ & 50,62 & $\mathrm{Bb}$ & 56,00 & $\mathrm{Ab}$ & 35,28 & $\mathrm{Aa}$ & \\
$\left(\mathrm{D}_{2}\right) 40 \%$ & 40,30 & $\mathrm{ABa}$ & 56,33 & $\mathrm{Bb}$ & 72,30 & $\mathrm{Bc}$ & 60,51 & $\mathrm{Cb}$ & 11,11 \\
$\left(\mathrm{D}_{3}\right) 60 \%$ & 54,42 & $\mathrm{Ca}$ & 52,06 & $\mathrm{Ba}$ & 60,62 & $\mathrm{Aa}$ & 56,58 & $\mathrm{BCa}$ & \\
\hline
\end{tabular}

Keterangan : Angka yang diikuti oleh huruf kapital yang sama pada lajur yang sama dan angka yang diikuti oleh huruf kecil yang sama pada baris yang sama berbeda tidak nyata pada taraf $5 \%$ (Uji BNJ ${ }_{0,05}$ ), $\mathrm{K}_{0}$; Kontrol, $\mathrm{K}_{1}$; Urea $100 \mathrm{~kg} / \mathrm{ha}+\mathrm{SP} 3650 \mathrm{~kg} / \mathrm{ha}+\mathrm{KCl} 25 \mathrm{~kg} / \mathrm{ha}, \mathrm{K}_{2}$; Urea $200 \mathrm{~kg} / \mathrm{ha}+\mathrm{SP} 36100$ $\mathrm{kg} / \mathrm{ha}+\mathrm{KCl} 50 \mathrm{~kg} / \mathrm{ha}, \mathrm{K}_{3} ; 300 \mathrm{~kg} / \mathrm{ha}+\mathrm{SP} 36150 \mathrm{~kg} / \mathrm{ha}+\mathrm{KCl} 75 \mathrm{~kg} / \mathrm{ha}$

\section{Panjang buah pertanaman (cm)}

Tabel 6. Rata-rata panjang buah terung akibat perlakuan dosis bahan organik dan kombinasi pupuk N, P dan K

\begin{tabular}{|c|c|c|c|c|c|c|c|c|}
\hline \multirow{2}{*}{$\begin{array}{c}\text { Dosis Bahan } \\
\text { Organik } \\
(\mathrm{cm})\end{array}$} & \multicolumn{7}{|c|}{ Kombinasi Pupuk N, P dan K } & \multirow[b]{2}{*}{ BNJ } \\
\hline & $\mathrm{K}_{0}$ & \multicolumn{2}{|r|}{$\mathrm{K}_{1}$} & \multicolumn{2}{|c|}{$\mathrm{K}_{2}$} & \multicolumn{2}{|c|}{$\mathrm{K}_{3}$} & \\
\hline$\left(\mathrm{D}_{0}\right) 0 \%$ & $15,50 \quad \mathrm{Aa}$ & 16,16 & $\mathrm{Aab}$ & 19,11 & $\mathrm{Abc}$ & 19,72 & Ac & \\
\hline$\left(D_{1}\right) 20 \%$ & $17,05 \mathrm{ABa}$ & 17,83 & $\mathrm{ABa}$ & 19,50 & $\mathrm{Aa}$ & 18,94 & $\mathrm{Aa}$ & 310 \\
\hline$\left(\mathrm{D}_{2}\right) 40 \%$ & $19,05 \mathrm{Ba}$ & 19,39 & $\mathrm{ABa}$ & 22,72 & $\mathrm{Bb}$ & 20,55 & $\mathrm{Aab}$ & 3,19 \\
\hline$\left(\mathrm{D}_{3}\right) 60 \%$ & $20,05 \mathrm{Ba}$ & 17,94 & $\mathrm{Ba}$ & 18,61 & Aa & 19,89 & $\mathrm{Aa}$ & \\
\hline
\end{tabular}

Keterangan : Angka yang diikuti oleh huruf kapital yang sama pada lajur yang sama dan angka yang diikuti oleh huruf kecil yang sama pada baris yang sama berbeda tidak nyata pada taraf $5 \%$ (Uji BNJ 0,05 ), $\mathrm{K}_{0}$; Kontrol, $\mathrm{K}_{1}$; Urea $100 \mathrm{~kg} / \mathrm{ha}+\mathrm{SP} 3650 \mathrm{~kg} / \mathrm{ha}+\mathrm{KCl} 25 \mathrm{~kg} / \mathrm{ha}, \mathrm{K}_{2}$; Urea $200 \mathrm{~kg} / \mathrm{ha}+\mathrm{SP} 36100$ $\mathrm{kg} / \mathrm{ha}+\mathrm{KCl} 50 \mathrm{~kg} / \mathrm{ha}, \mathrm{K}_{3} ; 300 \mathrm{~kg} / \mathrm{ha}+\mathrm{SP} 36150 \mathrm{~kg} / \mathrm{ha}+\mathrm{KCl} 75 \mathrm{~kg} / \mathrm{ha}$

\section{Diameter buah per tanaman $(\mathrm{cm})$}

Tabel 7. Rata-rata berat diameter buah tanaman terung akibat perlakuan dosis bahan organik dan kombinasi pupuk N, P dan $\mathrm{K}$

\begin{tabular}{|c|c|c|c|c|c|c|c|c|c|}
\hline \multirow{2}{*}{$\begin{array}{c}\text { Dosis Bahan } \\
\text { Organik } \\
(\mathrm{cm})\end{array}$} & \multicolumn{8}{|c|}{ Kombinasi Pupuk N,P dan K } & \multirow[b]{2}{*}{$\mathrm{BNJ}$} \\
\hline & \multicolumn{2}{|c|}{$\mathrm{K}_{0}$} & \multicolumn{2}{|l|}{$\mathrm{K}_{1}$} & \multicolumn{2}{|c|}{$\mathrm{K}_{2}$} & \multicolumn{2}{|c|}{$\mathrm{K}_{3}$} & \\
\hline$\left(\mathrm{D}_{0}\right) 0 \%$ & 4,13 & $\mathrm{Aa}$ & 4,55 & $\mathrm{Aa}$ & 4,81 & $\mathrm{Aa}$ & 4,99 & $\mathrm{Aa}$ & \\
\hline$\left(D_{1}\right) 20 \%$ & 5,05 & $\mathrm{ABa}$ & 5,04 & $\mathrm{Aa}$ & 5,07 & Aa & 4,81 & $\mathrm{Aa}$ & \\
\hline$\left(D_{2}\right) 40 \%$ & 4,83 & $\mathrm{Aa}$ & 5,00 & $\mathrm{Aa}$ & 6,39 & $\mathrm{Bb}$ & 5,68 & $\mathrm{Aab}$ & 0,96 \\
\hline$\left(D_{3}\right) 60 \%$ & 5,43 & $\mathrm{Bab}$ & 4,51 & $\mathrm{Aa}$ & 5,37 & $\mathrm{Aa}$ & 5,53 & $\mathrm{Ab}$ & \\
\hline
\end{tabular}

Keterangan : Angka yang diikuti oleh huruf kapital yang sama pada lajur yang sama dan angka yang diikuti oleh huruf kecil yang sama pada baris yang sama berbeda tidak nyata pada taraf $5 \%$ (Uji BNJ 0,05 ), $\mathrm{K}_{0}$; Kontrol, $\mathrm{K}_{1}$; Urea $100 \mathrm{~kg} / \mathrm{ha}+\mathrm{SP} 3650 \mathrm{~kg} / \mathrm{ha}+\mathrm{KCl} 25 \mathrm{~kg} / \mathrm{ha}, \mathrm{K}_{2}$; Urea $200 \mathrm{~kg} / \mathrm{ha}+\mathrm{SP} 36100$ $\mathrm{kg} / \mathrm{ha}+\mathrm{KCl} 50 \mathrm{~kg} / \mathrm{ha}, \mathrm{K}_{3} ; 300 \mathrm{~kg} / \mathrm{ha}+\mathrm{SP} 36150 \mathrm{~kg} / \mathrm{ha}+\mathrm{KCl} 75 \mathrm{~kg} / \mathrm{ha}$

$\overline{\text { Pertumbuhan dan Hasil Tanaman Terung ( Solanum melongena L.) pada Berbagai Dosis Bahan Organik dan }}$ Kombinasi Pupuk N, P dan K (Tajul Rina, Ashabul Anhar, Ainun Marliah) 


\section{Berat buah per tanaman (g)}

Tabel 8. Rata-rata berat buah tanaman terung akibat perlakuan dosis bahan organik dan kombinasi pupuk $\mathrm{N}, \mathrm{P}$ dan $\mathrm{K}$

\begin{tabular}{|c|c|c|c|c|c|c|c|c|c|}
\hline \multirow{2}{*}{$\begin{array}{c}\text { Dosis } \\
\text { Bahan } \\
\text { Organik }\end{array}$} & \multicolumn{8}{|c|}{ Kombinasi Pupuk N, P dan K } & \multirow[b]{2}{*}{ BNJ } \\
\hline & \multicolumn{2}{|l|}{ K0 } & \multicolumn{2}{|l|}{$\mathrm{K} 1$} & \multicolumn{2}{|l|}{$\mathrm{K} 2$} & \multicolumn{2}{|l|}{ K3 } & \\
\hline D0 $(0 \%)$ & 620,43 & $\mathrm{Aa}$ & 770,05 & Aab & 1214,27 & $\mathrm{ABc}$ & 931,83 & $\mathrm{ABbc}$ & \\
\hline D1 $(20 \%)$ & 1081,17 & $\mathrm{Ba}$ & 1465,13 & $\mathrm{Cb}$ & 1418,70 & $\mathrm{Bb}$ & 901,29 & $\mathrm{Aa}$ & \\
\hline D2 $(40 \%)$ & 1692,05 & $\mathrm{Ca}$ & 1983,78 & $\mathrm{Da}$ & 2497,62 & $\mathrm{Cb}$ & 1768,20 & $\mathrm{Ca}$ & 1, \\
\hline D3 $(60 \%)$ & 1139,49 & $\mathrm{Ba}$ & 1081,22 & $\mathrm{Ba}$ & 1077,97 & Aa & 1230,71 & $\mathrm{Bb}$ & \\
\hline
\end{tabular}

Keterangan : Angka yang diikuti oleh huruf kapital yang sama pada lajur yang sama dan angka yang diikuti oleh huruf kecil yang sama pada baris yang sama berbeda tidak nyata pada taraf $5 \%$ (Uji BNJ 0.05 ), $\mathrm{K}_{0}$; Kontrol, $\mathrm{K}_{1}$; Urea $100 \mathrm{~kg} / \mathrm{ha}+\mathrm{SP} 3650 \mathrm{~kg} / \mathrm{ha}+\mathrm{KCl} 25 \mathrm{~kg} / \mathrm{ha}, \mathrm{K}_{2}$; Urea $200 \mathrm{~kg} / \mathrm{ha}+\mathrm{SP} 36100$ $\mathrm{kg} / \mathrm{ha}+\mathrm{KCl} 50 \mathrm{~kg} / \mathrm{ha}, \mathrm{K}_{3} ; 300 \mathrm{~kg} / \mathrm{ha}+\mathrm{SP} 36150 \mathrm{~kg} / \mathrm{ha}+\mathrm{KCl} 75 \mathrm{~kg} / \mathrm{ha}$

Berdasarkan hasil analisis yang telah diuraikan menunjukkan bahwa terdapat interaksi yang sangat nyata antara dosis bahan organik dan kombinasi pupuk N, P, dan K terhadap parameter tinggi tanaman 30 HSPT, diameter buah pertanaman, berat buah pertanaman, berat berangkasan basah, dan berat berangkasan kering dan terdapat interaksi yang nyata terhadap parameter tinggi tanaman 45 HSPT. Namun tidak nyata terhadap parameter tinggi tanaman 15 HSPT, diameter batang 15, 30, dan 45 HSPT, jumlah daun 15 dan 45 HSPT, jumlah buah pertanaman.

Dari berbagai dosis pupuk organik dan kombinasi pupuk $\mathrm{N}, \mathrm{P}$ dan $\mathrm{K}$ yang telah dicobakan, pertumbuhan dan hasil tanaman terung yang terbaik dijumpai pada perlakuan dosis bahan orgnik 40\% $\left(\mathrm{D}_{2}\right)$ dan kombinasi pupuk N, P dan $\mathrm{K} \mathrm{K}_{2}$ (Urea $200 \mathrm{~kg}+\mathrm{SP} 36100$ $\mathrm{kg}+\mathrm{KCl} 50 \mathrm{~kg} / \mathrm{ha}$ ) dengan jumlah buah pertanaman 19,98 dan berat buah pertanaman 6,657 $\mathrm{g}$, sedangkan untuk pertumbuhan dan hasil tanaman terung yang terendah dijumpai pada perlakuan dosis bahan organik $0 \% \mathrm{D}_{0}$ (kontrol) dan kombinasi pupuk $\mathrm{N}, \mathrm{P}$ dan $\mathrm{K} \mathrm{K}_{0}$ (kontrol) dengan jumlah buah per tanaman 10,21 dan berat buah per tanaman 3,239 g.

Penelitian ini sesuai dengan yang dinyatakan oleh Prasatwi (2009) bahwa interaksi antara dosis bahan organik 40\% dan kombinasi pupuk N, P dan K (Urea $200 \mathrm{~kg}+$ SP36 100 $\mathrm{kg}+\mathrm{KCl} 50 \mathrm{~kg} / \mathrm{ha}$ ) pada tanaman cabai besar menunjukkan jumlah buah per tanaman tertinggi yaitu 41,74.

Pupuk organik dapat menambah bahan organik didalam tanah yang merupakan salah satu bahan pembentuk agregat tanah, yang berperan sebagai bahan perekat antar partikel tanah untuk bersatu menjadi agregat tanah. Mekanisme pembentukan agregat tanah oleh adanya peran bahan organik dapat digolongkan ke dalam empat bentuk, yaitu : (1) penambahan bahan organik dapat meningkatkan populasi mikroorganisme tanah, (2) pengikatan secara kimia butir-butir lempung akibat adanya gugus karboksil (3) pengikatan secara kimia butir-butir lempung melalui ikatan antara muatan lempung dengan gugus karboksil dengan perantaraan basa-basa seperti $\mathrm{Ca}, \mathrm{Mg}, \mathrm{Fe}$, dan ikatan Hidrogen dan (4) pengikatan secara kimia antara muatan negatif dari lempung dengan muatan positif (amida, amina dan amino) dari senyawa organik berantai panjang.

Dosis bahan organik dan kombinasi pupuk N, P, dan K yang sesuai dapat memberikan respon yang maksimal terhadap pertumbuhan dan produksi tanaman terung. Menurut Putri (2016), menyatakan bahwa Pemupukan yang ideal adalah apabila unsur hara yang diberikan dapat melengkapi unsur hara yang tersedia menjadi tepat. Sehingga unsur hara yang

Pertumbuhan dan Hasil Tanaman Terung ( Solanum melongena L.) pada Berbagai Dosis Bahan Organik dan 
mencukupi tersebut dapat memberikan hasil yang maksimal terhadap pertumbuhan dan hasil tanaman terung.

\section{KESIMPULAN}

Hasil penelitian ini menunjukkan bahwa dosis bahan organik berpengaruh sangat nyata terhadap pertumbuhan dan hasil tanaman terung pada parameter tinggi tanaman 30 HST, diameter batang umur 15, 30 dan 45 HST, julah daun 45 HST, jumlah buah pertanman, panjang buah pertanaman, diameter buah pertanaman, berat buah pertanaman dan berat berangkasan kering, namun berpengaruh nyata pada parameter berat berangkasan basah dan tidak berpengaruh nyata pada parameter tinggi tanaman umur 15 dan 45 HST, jumlah daun umur 15 dan 30 HST. Pertumbuhan dan hasil tanaman terung terbaik dijumpai pada perlakuan dosis bahan organik $40 \%$. Kombinasi pupuk N, P dan k sangat berpengaruh nyata terhadap pertumbuhan dan hasil tanaman terung pada parameter tinggi tanaman $30 \mathrm{HST}$, diameter batang 15,30 dan 45 HST, panjang buah pertanaman, diameter buah pertanaman, berat buah pertanaman, berat berangkasan basah dan berat berangkasan kering, namun tidak berpengaruh nyata pada parameter lainnya. Pertumbuhan dan hasil tanaman terung terbaik dijumpai pada perlakuan kombinasi pupuk N, P, dan K $\left(\mathrm{K}_{2}\right)$ (Urea $200 \mathrm{~kg}+\mathrm{SP} 36100 \mathrm{~kg}+\mathrm{KCl} 75 \mathrm{~kg} / \mathrm{ha}$.) Interaksi antara dosis bahan organik dan kombinasi pupuk $\mathrm{N}, \mathrm{P}$, dan $\mathrm{K}$ berpengaruh sangat nyata antara dosis bahan organik dengan $\mathrm{N}, \mathrm{P}$ dan $\mathrm{K}$ pada parameter panjang buah pertanaman, diameter buah pertanaman, berat buah pertanaman, berat berangkasan basah dan berat berangkasan kering. Namun berpengarun nyata pada parameter tinggi tanaman 30 HST dan tidak berpengaruh nyata pada parameter lainnya. Hasil interaksi antara dosis bahan organik dan kombinasi pupuk $\mathrm{N}, \mathrm{P}$, dan $\mathrm{K}$ terbaik dijumpai pada kombinasi perlakuan dosis bahan organik 40\% dan perlakuan kombinasi pupuk N, P, dan $\mathrm{K}_{2}$ (Urea $200 \mathrm{~kg}+\mathrm{SP} 36100$ $\mathrm{kg}+\mathrm{KCl} 75 \mathrm{~kg} / \mathrm{ha})$.

\section{DAFTAR PUSTAKA}

Alamtani. 2018. Agrosiana. https://alamtani.com/pupuk-kandang/. Diakses tanggal: 28 Oktober 2018.

Doni, S., P. Astuti dan A. P. Sujalu. 2015. Pengaruh dosis pupuk kandang sapi terhadap pertumbuhan dan hasil tanaman terung ungu dan terung hijau (Solanum melongena L.). Jurnal AGRIFOR (14) 1.

Firmanto, B. 2011. Sukses Bertanaman Terung Secara Organik. Angkasa, Bandung. 50 hal.

Firmansyah, I., M. Syakir, dan L. Lukman. 2017. Pengaruh Kombinasi Dosis Pupuk N, P, dan K Hasil Tanaman Terung (Solanum melongena L.). J. Hort. 27 (1).

Luthfyrakhman, H. 2012. Optimasi Dosis Pupuk Anorganik Dan Pupuk Kandang Ayam Pada Budidaya Tomat Hibrida (Lycopersicon Esculentum Mill. L.). Departemen Agronomi Dan Hortikultura. Fakultas Pertanian Institut Pertanian Bogor. 
Maryanto dan A. Rahmi. 2015. Pengaruh Jenis Dan Dosis Pupuk Organik Terhadap Pertumbuhan Dan Hasil Tanaman Tomat (Lycopersicum Esculentum Mill) Varietas Permata. Jurnal Agrifor. 14 (1).

M. C. Ichsan, P. R. Yandikan dan I. Wijaya. 2015. Respon produktifitas okra (Abelmoschus esculentum) terhadap pemberian dosis pupuk petroganik dan pupuk N. Skripsi. Fakultas Pertanian Universitas Muhammadiyah Jember.

Prasatwi, D. 2019. Uji Efektifitas Penggunaan Pupuk Organik npk Terhadap Tanaman Cabai Besar (Capsicum Annum L.) Varietas Hot Beauty. Skripsi Program Studi Hortikultura Fakultas Pertanian Institut Pertanian Bogor.

Simatupang, A. 2010. Pengaruh beberapa jenis pupuk organik terhadap pertumbuhan dan hasil tanaman terung (Solanum melongena L.). Skripsi. Fakultas Pertanian Universitas Andalas, Padang.

Santoso dan Oktariana. 2016. Uji efektivitas waktu aplikasi bahan organik dan dosis pupuk SP36 dalam meningkatkan produksi okra (Abelmoschus esculentum). Skripsi. Fakultas Pertanian Universitas Muhammadiyah Jember. 